ISSN 0122-5383

\title{
OBTAINING HIGH VALUE PRODUCTS IN A BIOREFINERY TOPOLOGY USING MICROALGAE
}

\author{
OBTENCIÓN DE PRODUCTOS DE ALTO VALOR AGREGADO EN UNA \\ TOPOLOGÍA DE BIOREFINERÍA UTILIZANDO MICROALGAS
}

\author{
Ángel-Dario González-Delgado ${ }^{1 *}$, Andrés-Fernando Barajas-Solano ${ }^{2}$ and Viatcheslav Kafarov² \\ 'Universidad de San Buenaventura, Cartagena, Bolívar, Colombia \\ ${ }^{2}$ Universidad Industrial de Santander, Bucaramanga, Santander, Colombia \\ e-mail: cisyc@uis.edu.co
}

(Received: Jul. 24, 2012; Accepted: Sep. 05, 2013)

\section{ABSTRACT}

$\mathrm{M}$ icroalgae biomass presents high potential for third-generation biofuel production. It also contains other products whose recovery can contribute to the sustainability of linear biofuel production chains. These substances are currently treated as impurities that are extracted along with lipids, causing a negative influence on the biodiesel production process. Therefore, the separation of these substances has a dual benefit. On one hand, high value products are obtained, and on the other, purer oil is produced for the generation of biofuel, approaching the biorefinery concept.

This study proposes the incorporation of a chlorophyll production stage in a biorefinery topology. The variables affecting the separation of these components are evaluated along with the most appropriate location of the stage in the process diagram. The best conditions for the separation of pigments from lipids are given at a biomass/solvent ratio of $1 / 10 \mathrm{~g} / \mathrm{mL}$, a temperature of $45^{\circ} \mathrm{C}$ and a time of $4 \mathrm{~h}$, where the biomass/solvent ratio is the most influential variable. The highest efficiency for obtaining high-value products is achieved by incorporating the process before the biomass drying stage.

Keywords: Biomass, Biofuels, Chlorophyll, Production.

How to cite: González-Delgado, A. D., Barajas-Solano, A. F. \& Kafarov, V. (2013). Obtaining high value products in a biorefinery topology using microalgae. CT\&F - Ciencia, Tecnología y Futuro, 5(3), 95-106.

*To whom correspondence should be addressed

+V Congreso Internacional de Ciencia y Tecnología de los Biocombustibles, CIBSCOL 2012, Universidad Industrial de Santander, Bucaramanga, Santander, Colombia. 5 - 8 de junio de 2012. 


\title{
RESUMEN
}

I

a biomasa de microalgas presenta un alto potencial para la obtención de biocombustibles de tercera generación. Ésta además contiene otros productos cuya recuperación puede contribuir a la sostenibili-

dad de las cadenas lineales de producción de biocombustibles. Estas sustancias actualmente se tratan como impurezas que se extraen junto con los lípidos influyendo negativamente en el proceso de producción de biodiesel, por lo que su separación produce un doble beneficio: por un lado, la obtención de productos de alto valor agregado y por otro, la producción de un aceite más puro para la generación del biocombustible, abordando el concepto de biorefinería.

En este estudio, se plantea la incorporación de una etapa de obtención de clorofila dentro de una topología de biorefinería, se evalúan las variables que afectan la separación de estos componentes y la localización más adecuada de la etapa dentro del esquema de proceso. Las mejores condiciones para la separación de pigmentos de los lípidos, se dan a una relación biomasa/solvente de $1 / 10 \mathrm{~g} / \mathrm{mL}$, temperatura de $45^{\circ} \mathrm{C}$ y tiempo de $4 \mathrm{~h}$, siendo la relación biomasa/solvente la variable más influyente. La mayor eficiencia de obtención de productos de alto valor se consigue al incorporar el proceso antes de la etapa de secado de la biomasa.

Palabras clave: Biomasa, Biocombustibles, Clorofila, Producción.

\section{RESUMO}

\begin{abstract}
A
biomassa de microalgas apresenta um alto potencial para a obtenção de biocombustíveis de terceira geração. Além disso, contém outros produtos cuja recuperação pode contribuir para a sustentabilidade das cadeias lineares de produção de biocombustíveis. Estas substâncias atualmente são tratadas como impurezas que são extraídas junto com os lipídios influenciando negativamente no processo de produção de biodiesel, devido a isso sua separação produz um benefício duplo: por um lado a obtenção de produtos de alto valor agregado e, por outro a produção de um óleo mais puro para a geração do biocombustível, abordando o conceito de biorefinaria.
\end{abstract}

Neste estudo, é proposta a incorporação de uma etapa de obtenção de clorofila dentro de uma topologia de biorefinaria, são avaliadas as variáveis que afetam a separação destes componentes e a localização mais adequada da etapa dentro do esquema de processo. As melhores condições para a separação de pigmentos dos lipídios ocorrem em uma relação biomassa/solvente de $1 / 10 \mathrm{~g} / \mathrm{mL}$, temperatura de $45^{\circ} \mathrm{C}$ e tempo de 4 h, sendo a relação biomassa/solvente a variável mais influente. A maior eficiência de obtenção de produtos de alto valor é conseguida ao incorporar o processo antes da etapa de secagem da biomassa.

Palavras-chave: Biomassa, Biocombustíveis, Clorofila, Produção. 


\section{INTRODUCTION}

At present, the continuous use of petroleum-based fuels as a source of energy is unsustainable, given its non-renewable origin that is directly related to the development of crude oil by progressively depleting the reserves available, leading to an increase in fuel prices around the world, among other consequences (Tverberg, 2012). From the environmental standpoint, there is a negative impact perceived as a result of the mass use of fossil fuels in terms of $\mathrm{CO}_{2}$ emissions, which cause global warming along with other compounds (EPA, 2011). These environmental and economic factors have led to the consideration of non-conventional alternatives for the production of fuels to meet requirements as clean, renewable sources of energy.

Biofuel production is globally perceived as a viable option because it covers three strategic objectives: energy security, economic prosperity and environmental stability, which is why specialists around the world have focused on the study of this energy source. Biofuels can be obtained from renewable resources such as biomass, thus preventing the net contribution of greenhouse gases into the atmosphere. This way, the $\mathrm{CO}_{2}$ resulting from combustion can be used in the formation of new biomass.

Microalgae biomass is among the raw materials currently being studied with the greatest interest for biofuel production because it has been demonstrated that it can provide a wide variety of compounds of biotechnological interest. Microalgae biomass is usually made up of 20 - 30\% usable lipids for biodiesel production, 20 - 55\% carbohydrates for the production of ethanol, 40 - 50\% protein, which can be used as a nitrogen source in various applications and the rest is made up of other special substances that are typical of each strain of microalgae (Amaro, Guedes \& Malcata, 2011).

Up to now, however, the linear chains of biofuel production using microalgae cannot process large-scale biomass due to technical and economic factors. In order not to miss out on the huge potential of this raw material González-Delgado and Kafarov (2011) suggested alternative routes for the integral use of microalgae biomass, including the valorization of residual biomass from the extraction of oil for biodiesel production by obtaining other high-value products, as well as the incorporation of the biorefinery concept in microalgae processing.

This paper proposes the incorporation of a stage to extract certain high-value products using microalgae such as chlorophylls in the conceptual designs of thirdgeneration biodiesel and bioethanol production chains, by studying the variables that affect the separation of these components for a strain of national bioprospecting. It also examines the operating conditions for better extraction efficiency and the subsequent execution of the optimized procedure at different stages of the biofuel production chain based on microalgae, with a triple benefit as a direct impact:

- Separation of unwanted microalgae components at the microalgae oil extraction stages and the subsequent transformation thereof into biodiesel.

- Production of high value co-products using unwanted substances from the useful metabolites for the production of biofuels.

- Approximation of the use of microalgae biomass to the biorefinery concept, conceiving the integration of a process of total biomass use, thus improving the efficiency of the variables of the different processes to obtain products of interest such as biofuels.

\section{THEORETICAL FRAMEWORK}

Microalgae were the first organisms with the capacity to carry out photosynthesis and one of the agents in the creation of the earth's current atmosphere. These organisms are key elements in planetary balance, because they determine to a large extent the dynamics of carbon dioxide on earth and they are the basis of the food chain in the oceans (Richmond, 2004). These microorganisms can grow quickly and live in harsh conditions thanks to their cell structure. They convert sunlight, water, inorganic nutrients and carbon dioxide into biomass, efficiently producing lipids, carbohydrates and proteins in different proportions. It is estimated that 
there are more than 50000 species of microalgae, but only about 30000 have been analyzed (Mata, Martins \& Caetano, 2010).

Microalgae biomass stands out as a promising source of energy, as it has been demonstrated that it can provide various products that are usable in energy systems such as methane produced by the anaerobic digestion of biomass, biodiesel from oil, biohydrogen and bioethanol (Pragya, Pandey \& Sahoo, 2013). Over the last five years, research on microalgae for biofuel production has been focused on biodiesel due to its high oil productivity per area unit (Chisti, 2007), which means less land is required for cultivation and it does not compete directly with food crops. Various authors have contributed to the optimization of the stages in growing microalgae, in open ponds (Handler et al., 2012) as well as in photobioreactors, (Pegallapati, Arudchelvam \& Nirmalakhandan, 2012) biomass harvesting (Garzón-Sanabria, Davis \& Nikolov, 2012), oil extraction (González-Delgado \& Kafarov, 2012; Halim, Danquah \& Webley, 2012) and transesterification for conversion into biodiesel (Ehimen, Sun \& Carrington, 2010) or hydrotreatment for transformation into Green-diesel. We have also developed approaches to large-scale processing of microalgae using software for the entire biodiesel production chain using microalgae (Ofori-Boateng, Teong \& JitKang, 2012) and for particular stages comparing existing and emerging technologies for extracting oil (Peralta-Ruiz, González-Delgado \& Kafarov, 2013) and converting it into biodiesel.

Among the microalgae's different metabolites, there are various products of high commercial value such as chlorophylls, which are essential in many everyday products. They also have medicinal and therapeutic applications (Schumann, Häubner, Klausch \& Karsten, 2005). However, these components are not used in biofuel production chains, and since the methods used in the processes of cell wall destruction and extraction are not selective, other metabolites (often unwanted) are obtained. This situation affects the purity of liquors rich in reducing sugars and triglycerides used in fermentation processes and transesterification respectively, and causing interference in the quantification of total lipids at the laboratory scale (Archanaa, Moise \& Suraishkumar, 2012).
The biorefinery concept is based on processing biomass in a sustainable manner to obtain energy, biofuels and high value products through processes and equipment for biomass transformation. Microalgae are cataloged as promising candidates in biorefinery processes due to their varied composition and biotechnology potential, seeking the total use of their biomass (González-Delgado \& Kafarov, 2011), obtaining not only a lipid extract for biodiesel production, but also valuable by-products, whose higher commercial value can contribute to the viability of the chain of biofuel production from microalgae. Figure 1 illustrates the valorization of products produced from microalgae biomass.

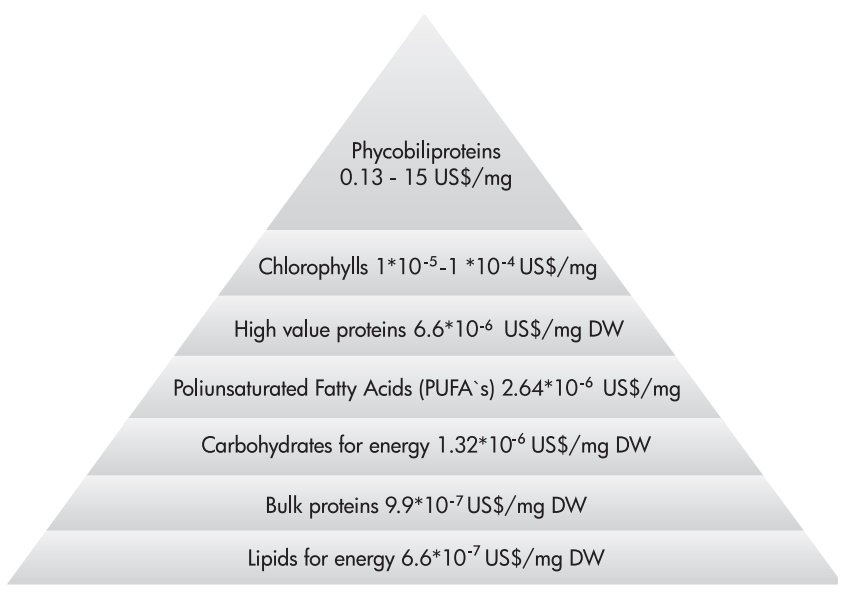

Figure 1. Cost comparison of the various components of microalgae biomass (modified from Ramírez \& Olvera, 2006; Wijffels, Barbosa \& Eppink, 2010).

\section{EXPERIMENTAL DEVELOPMENT}

We used dry biomass of Amphiprora sp. provided by Corporación Instituto de Morrosquillo (Punta Bolívar, Colombia), which was grown for 15 days in an F/2 medium. Two types of solvent were evaluated for chlorophyll and lipid extraction: polar (ethanol, methanol) and non polar (hexane, cyclohexane). In each experiment, $3 \mathrm{~g}$ of dry biomass were used in order to homogenize it. The biomass was macerated using a ceramic mortar. After that, the polar solvent was added as a biomass/solvent ratio of 1:10 $\mathrm{g} / \mathrm{mL}$. Then, the biomass-solvent mixture was stirred at $350 \mathrm{rpm}$ and ambient temperature for 24 hours. Later, the mixture was filtered by vacuum and was washed with the solvent used in each experiment 
(ethanol or methanol) until colorless cells were obtained. The pigments from the liquid phase were quantified. To purify the extract, $6 \mathrm{~mL}$ of non polar solvent and 4 $\mathrm{mL}$ of distilled water were added to the liquid phase in order to separate the phases. They were taken through a separating funnel and the lipophilic phase was extracted. This process was repeated four more times to ensure the effective separation of oil from microalgae. Finally, solvent was separated by volatilization in order to obtain the lipid extract to make the respective calculations.

Once the solvent mixture was obtained for the extraction of pigments and lipid extract, a central composite design was made for a confidence interval of $95 \%$ using STATISTICA 7.0 to evaluate the effect of the variables of temperature $\left(35,45\right.$ and $\left.55^{\circ} \mathrm{C}\right)$, time (2, 4 and $6 \mathrm{~h}$ ) and biomass/solvent ratio (1/30, 1/60 and $1 / 90 \mathrm{~g} / \mathrm{mL}$ ) in the stirring stage of the chlorophyll-a and crude oil extraction. A replica was made of each combination suggested by the experimental design in order to reinforce the results by comparing the data obtained between the different levels and data from the same combination. Table 1 shows the values and levels of the variables studied.

The pigments were quantified by measuring the extracts from the hydroalcoholic phase following vacuum filtration in a UV-visible spectrophotometer (Spectroquant Pharo 300 Merck) at 665 and $650 \mathrm{~nm}$. Using Equation 1, where Chl-a is the concentration of chlorophyll- $a$ in $\mathrm{mg} / \mathrm{L}$. The data were standardized in order to rule out erroneous results by diluting the components at a larger volume of solvent.

Chl-a $[m g / L]=\left(16.5 * \mathrm{~A}_{665}\right)-\left(8.3 * \mathrm{~A}_{650}\right)$
For lipid extraction, the residual biomass was carried out in a Soxhlet extractor with $250 \mathrm{~mL}$ of the non polar solvent selected. The lipids were extracted from the biomass by heating through 18 hours. The non polar solvent is later recovered by simple distillation, and the lipid extract is subjected to volatilization up to constant weight. Chlorophyll and lipid extract percentages were calculated using Equation 2.

$\%$ ext $=\frac{\text { Mcomp. }}{\text { Mbiomass }} * 100 \%$

\section{RESULTS}

\section{Selection of Extraction Solvents and Purification of High-Value Products}

The results in Figure 2 show that the best solvent for extraction of desired high value products was ethanol, because it increased the amount of chlorophyll extracted compared to methanol. This result confirms the efficiency of said solvent for chlorophyll extraction in microalgae of the Naviculales order. In addition, ethanol has advantages to be taken into account for biorefinery development, such as low toxicity compared to methanol and the possibility of production from the fermentation of cellulosic material.

Figure 3 shows the results of purification of crude extract from chlorophyll by adding a neutral solvent that is similar to other metabolites that are present, for extraction with methanol, as well as with ethanol. It is noted that by using a mixture of cyclohexane/methanol,

Table 1. Experimental design of the variables studied.

\begin{tabular}{|c|c|c|c|c|c|}
\hline \multirow{2}{*}{ Factors } & \multicolumn{5}{|c|}{ Levels } \\
\hline & -1.68 & -1 & 0 & 1 & 1.68 \\
\hline Biomass/Solvent Ratio $(\mathrm{g} / \mathrm{mL})$ & $1 / 10$ & $1 / 30$ & $1 / 60$ & $1 / 90$ & $1 / 110$ \\
\hline Temperature $\left({ }^{\circ} \mathrm{C}\right)$ & 28.3 & 35.0 & 45.0 & 55.0 & 61.7 \\
\hline Time (h) & 0.65 & 2 & 4 & 6 & 7.35 \\
\hline
\end{tabular}




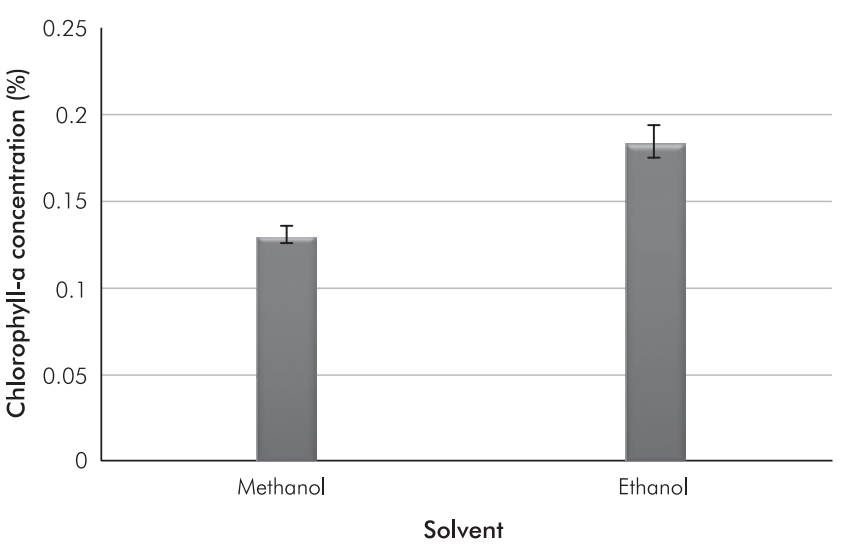

Figure 2. Evaluation of two non polar solvents (ethanol and methanol) to separate chlorophyll-a from the microalgae Amphiprora sp.

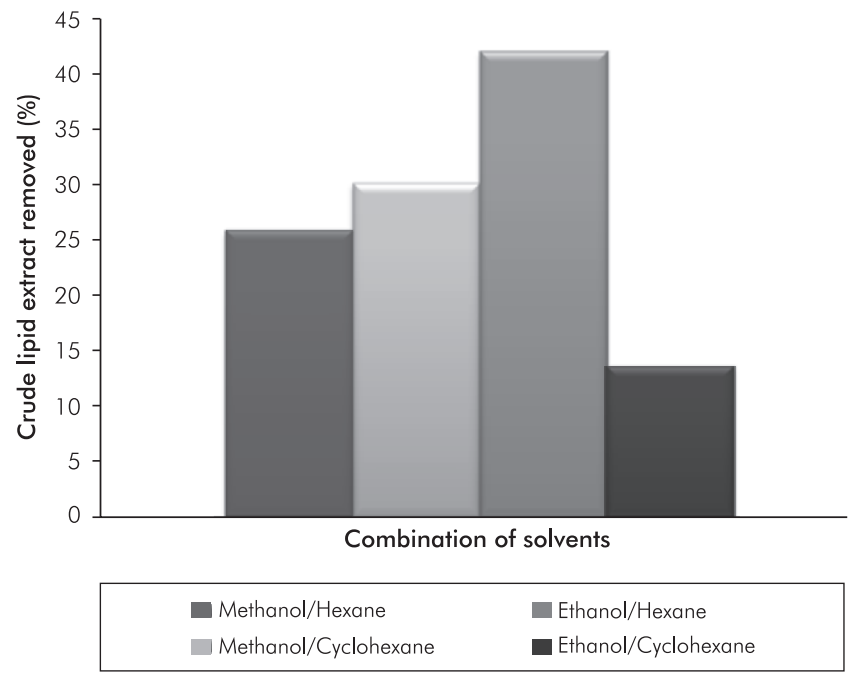

Figure 3. Comparison of non polar and non polar solvent mixtures for the extraction and purification of chlorophylls using the microalgae Amphiprora sp.

a larger quantity of crude extract is removed. This means that the use of methanol on chlorophyll extraction drags a larger quantity of non polar metabolites, which are consi-dered impurities of the product to be obtained, and they, in turn, are effectively removed with cyclohexane. It can also be seen in Figure 3 that the lowest percentage of crude extract removal is from the ethanol/cyclohexane mixture. This is due to the fact that, although ethanol and cyclohexane have low miscibility at the temperature of extraction of the high value products, there is little difference between the polarities of the solvents, which makes it difficult for the components from the hydrophilic phase to migrate to the hydrophobic phase. For the cases in which hexane was used as a purification solvent of the crude extract, the differences between removal percentages were not significant. This may be due to the fact that hexane has a low miscibility with ethanol as well as with methanol.

Based on the results obtained in this section, it can be said that for the extraction and purification of high value products such as chlorophylls, a mixture of ethanol/hexane should be used because the polar solvent generates more products of interest compared to methanol and, considering the biorefinery concept, this solvent is potentially obtainable by transforming microalgae components such as cellulose and hemicellulose. Furthermore, adding hexane increases the removal of hydrophobic components from the crude extract regardless of the type of polar solvent used. In addition, from the economic standpoint, it is a less expensive solvent than cyclohexane, which favors process economy.

\section{Influence of Different Variables in the Extraction of Chlorophyll-a}

Figure 4 shows the effect of the variables studied on the extraction of chlorophyll-a using the ethanol-hexane solvent mixture. The response surface diagrams show that the performance of the extraction decreases significantly upon increase of extraction time and quantity of solvent used for a constant temperature. This may be due to degradation of the high value component studied. The diagram of the response surface for a constant time (Figure 4c) also shows the decrease in the chlorophyll- a; percentage obtained at high biomass/solvent ratios. This degradation may be due to factors such as changes in $\mathrm{pH}$ resulting from the presence of flocculant, presence of water in the extraction solvent or favorable operating conditions for the generation of phaeophytins and pyrophaeophytins. The aforementioned are consequence of the consecutive reaction at low temperatures.

The Pareto diagram (Figure 4a) shows that the only significant variable in the extraction of chlorophyll-a from the microalgae Amphiprora sp. is the biomass/ solvent ratio, and its effect is inversely proportional, as well as the effect of the extraction time variable. It is important to point out that interaction between extraction time and biomass/solvent ratio has a positive effect on extraction. 


\section{Influence of the Stage of Extraction of Products with High Added Value on the Efficiency of Oil Extraction for Biodiesel Production}

According to the results illustrated in Figure 5, the inclusion of a prior stage to obtain high value products affects the efficiency of crude oil extraction from microalgae at a later stage, and the magnitude of this effect changes based on the different variables studied at the chlorophyll extraction stage. The effect is almost null when metabolites are extracted at high biomass/ solvent ratios over prolonged times (Figure 5b) and event tends to be negative at high biomass/solvent ratios and high temperatures (Figure 5c).
The increase in the quantity of lipids obtained when chlorophylls are extracted at low biomass/solvent ratios and high temperatures may be due to the fact that the operating conditions that allow increased chlorophyll extraction weaken the cell wall of the microalgae by decomposing the cellulosic material present therein. This allows increased contact between the hexane and oil in the following stage of lipid extraction, facilitating the obtainment of crude oil. However, analysis of the magnitude of variations in extraction efficiency shows that they do not exceed 2\% upon increase, and $0.3 \%$ upon decrease, which is low compared to extraction efficiencies obtained at the laboratory scale for this

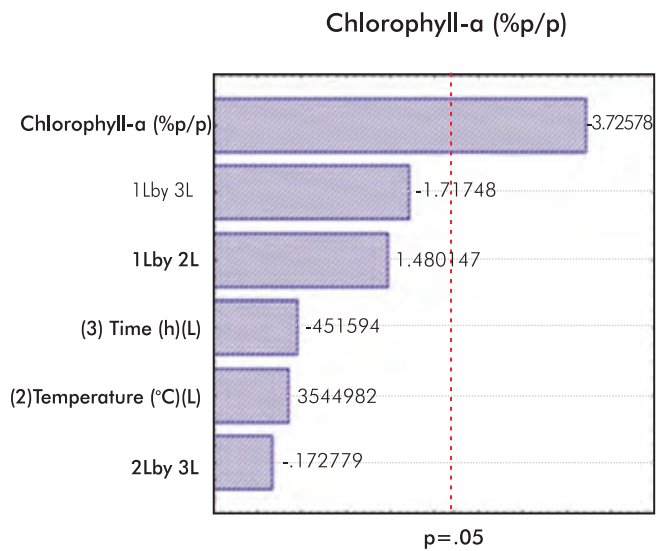

Estimated Standarized Effect (Absolute Value)

(a)

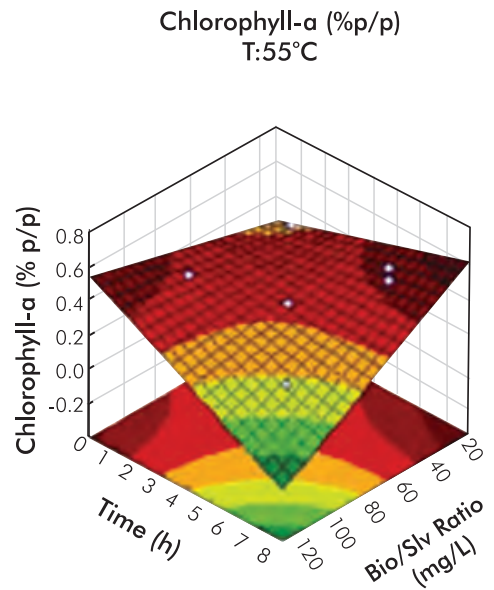

(b)

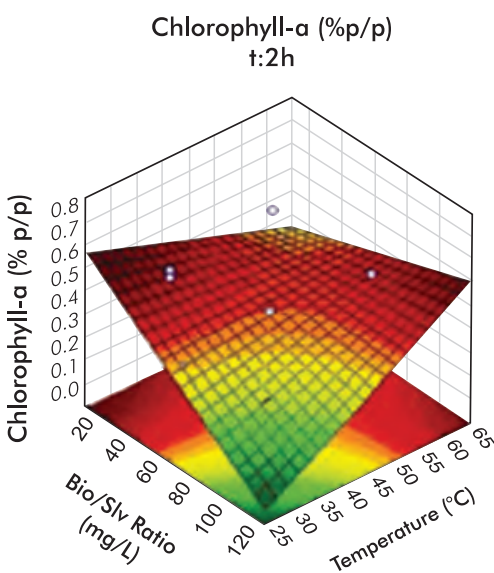

(c)

Figure 4. Effect of the variables of time, temperature, biomass/solvent ration and the combination thereof on the extraction of chlorophyll-a from the microalgae Amphiprora sp. (a) pareto diagram. (b) response surface diagram at $55^{\circ} \mathrm{C}$. (c) response surface diagram at $2 \mathrm{~h}$.

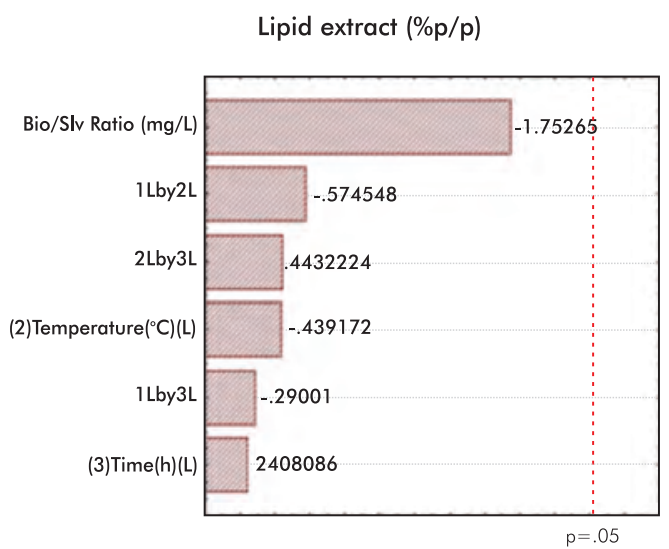

Estimated Standarized Effect (Absolute Value)

(a)

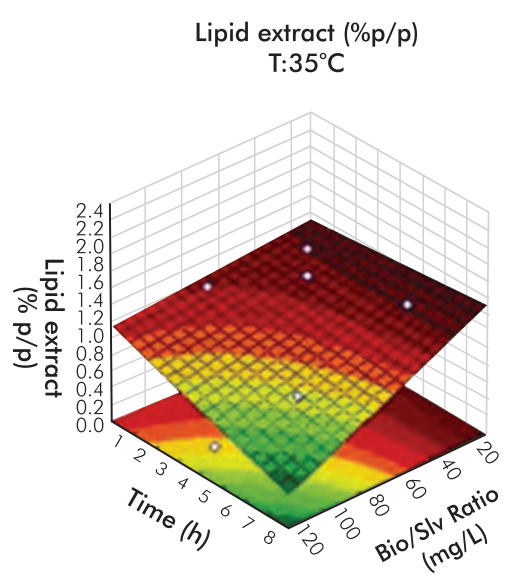

(b)

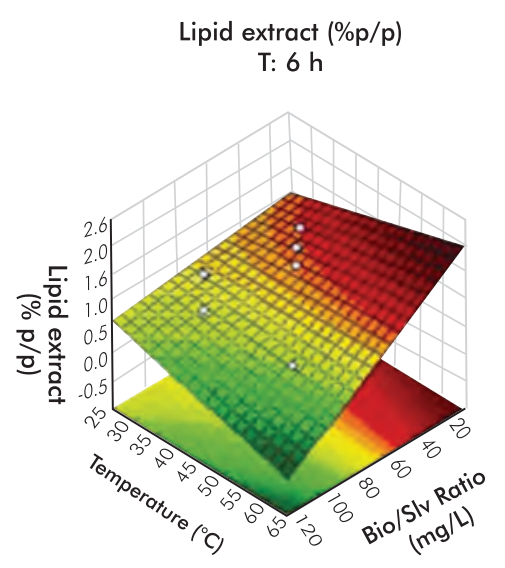

(c)

Figure 5. Effect of the variables of time, temperature, biomass/solvent ratio and the combination thereof evaluated in the extraction of chlorophylls and phycobiliproteins, in the efficiency of oil extraction increase from the microalgae Amphiprora sp. for biodiesel production. (a) Pareto diagram.

(b) response surface diagram at $55^{\circ} \mathrm{C}$. (c) response surface diagram at $6 \mathrm{~h}$. 
strain at 92\%. The Pareto diagram shows that none of the variables studied to obtain products with high added value significantly affect lipid extraction (Figure 5c).

\section{Selection of Operating Conditions for the Extraction of Microalgal Metabolites}

The results of the central composite design show that extraction percentages are low compared to those obtained with other strains such as S. platensis for the case of phycobiliproteins (Silveira, Burkert, Costa, Burkert \& Kalil, 2007). This behavior may be attributed to factors such as the nature of the strain, which does not produce large quantities of chlorophylls, the quantity of ash from the biomass harvesting stage, and the preliminary microalgae drying stage, which can degrade the metabolites of interest.

\section{Location of the Stage of Extraction of Products with High Added Value in a Microalgae-Based Biorefinery}

Based on the low percentages of chlorophyll obtained using microalgae biomass from the drying stage, we decided to test extraction with optimal operating conditions obtained at the end of the microalgae harvesting stage, and following the cell disruption stage. This process was performed in order to compare the percentages of metabolites obtained. Figure 6 illustrates the three alternatives for the location of the chlorophyll extraction stage with the respective extraction efficiencies, which can be present after biomass drying and before cell disruption (Figure 6a), after cell wall disruption but before lipid extraction (Figure 6b), or after harvesting and before drying (Figure 6c). It is clear that extraction efficiencies are higher when using moist biomass from

Table 2. Results of the different pigments and lipids extracted.

\begin{tabular}{|c|c|c|c|c|c|c|}
\hline \multirow{2}{*}{ Test } & \multirow{2}{*}{ Block } & \multirow{2}{*}{$\mathrm{T}\left({ }^{\circ} \mathrm{C}\right)$} & \multirow{2}{*}{$t(h)$} & \multirow{2}{*}{$\begin{array}{c}\text { Biomass/Solvent } \\
\text { Ratio } \\
(\mathrm{g} / \mathrm{mL})\end{array}$} & \multicolumn{2}{|c|}{ Percentages Extracted (\%) } \\
\hline & & & & & $\mathrm{Chl}-\mathrm{a}$ & Ext. Lipid \\
\hline 1 & 1 & 35 & 6 & 90 & 0.17 & 0.74 \\
\hline 2 & 1 & 55 & 6 & 30 & 0.51 & 0.85 \\
\hline 3 & 1 & 55 & 2 & 90 & 0.50 & 0.12 \\
\hline 4 & 1 & 45 & 4 & 60 & 0.26 & 0.12 \\
\hline 5 & 1 & 35 & 2 & 30 & 0.46 & 0.75 \\
\hline 6 & 2 & 45 & 4 & 60 & 0.24 & 1.54 \\
\hline 7 & 2 & 35 & 2 & 90 & 0.17 & 1.41 \\
\hline 8 & 2 & 55 & 6 & 90 & 0.18 & 0.72 \\
\hline 9 & 2 & 35 & 6 & 30 & 0.44 & 1.21 \\
\hline 10 & 2 & 55 & 2 & 30 & 0.26 & 0.85 \\
\hline 11 & 3 & 45 & 4 & 110 & 0.16 & 0.04 \\
\hline 12 & 3 & 45 & 4 & 60 & 0.32 & 1.86 \\
\hline 13 & 3 & 45 & 4 & 10 & 0.69 & 2.13 \\
\hline 14 & 3 & 45 & 7.35 & 60 & 0.21 & 0.60 \\
\hline 15 & 3 & 28.3 & 4 & 60 & 0.27 & 0.35 \\
\hline 16 & 3 & 45 & 0.65 & 60 & 0.26 & 0.49 \\
\hline 17 & 3 & 61.7 & 4 & 60 & 0.22 & 0.66 \\
\hline
\end{tabular}


the harvesting stage (Figure $6 \mathrm{c}$ ), which shows that both biomass flocculation and drying affect the content and extractability of the components, due to the fact that biomass drying temperature is $105^{\circ} \mathrm{C}$, which is higher than chlorophyll degradation temperature. Water content in post-harvesting biomass does not affect the extraction efficiency of the products as significantly as the drying process, so the results show it is better to incorporate this stage prior to the microalgae drying stage.

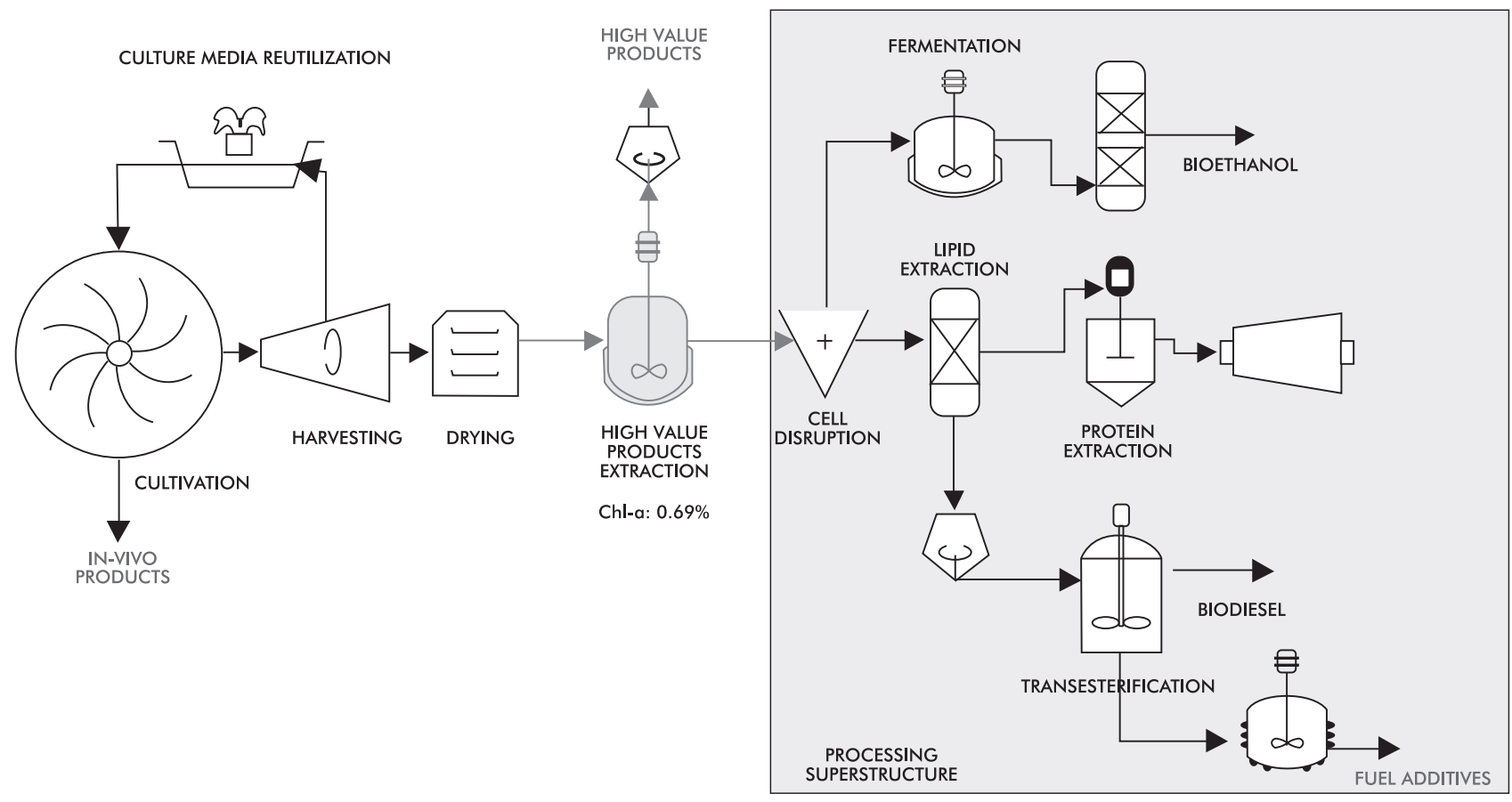

(a)

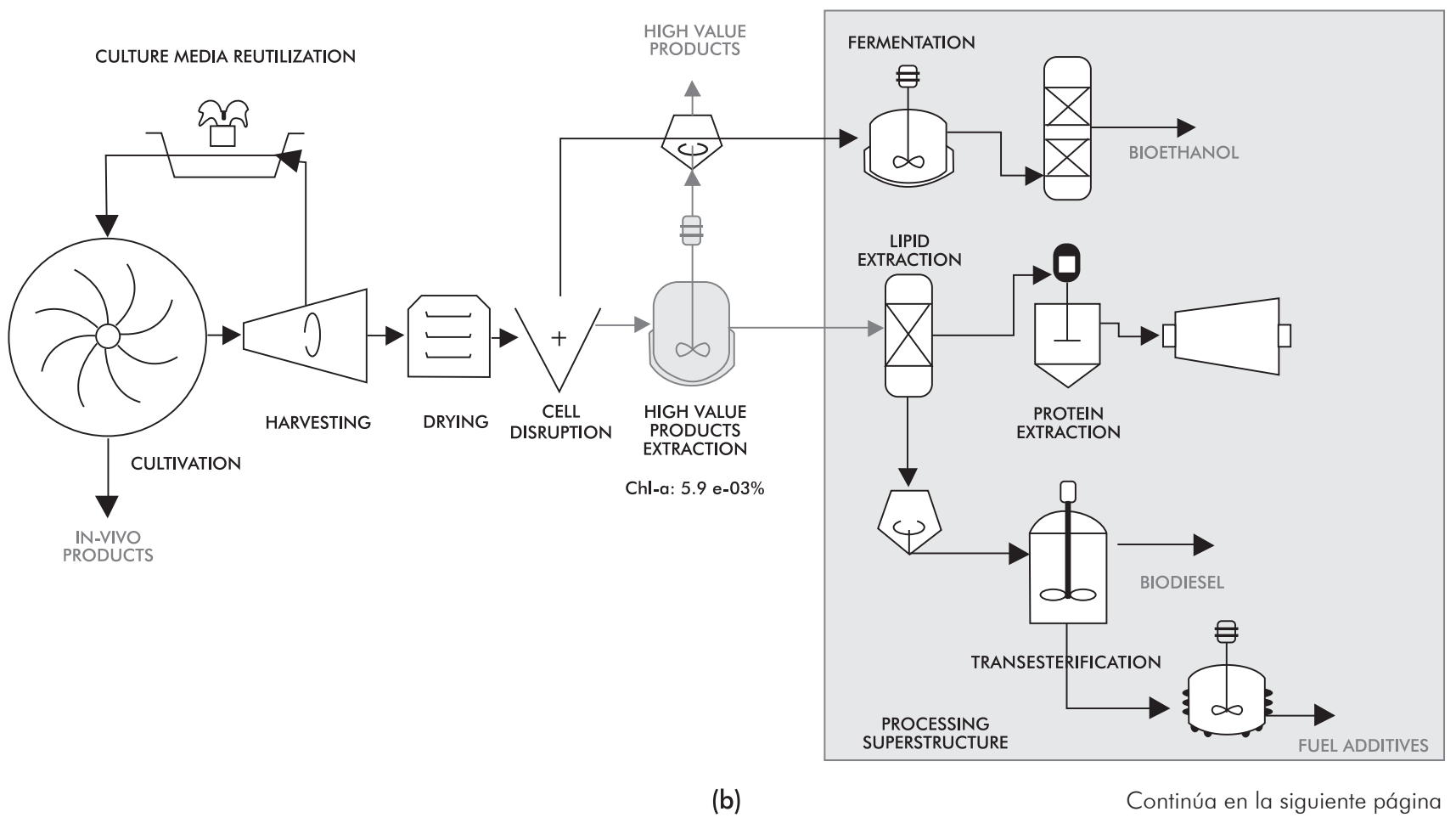




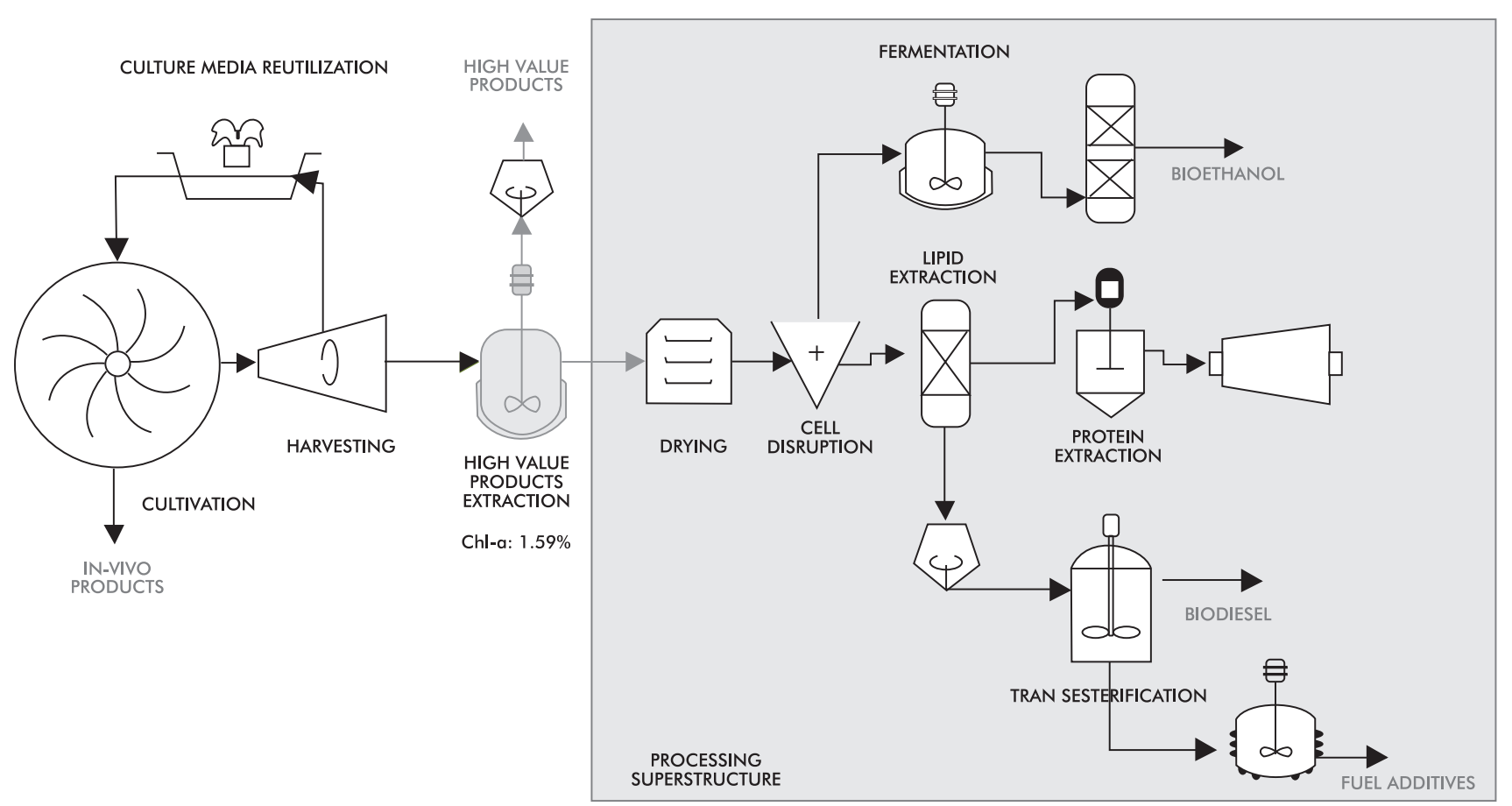

(c)

Figure 6. Chlorophyll extraction efficiencies when implementing the stage to extract high value products at different stages of a microalgaebased biorefinery configuration, (a) prior to the cell disruption stage, (b) prior to the oil extraction stage, and (c) prior to the biomass drying stage.

\section{CONCLUSIONS}

- The microalgae Amphiprora sp. is a promising strain for the development of a microalgae-based biorefinery due to the presence of special high-value substances in the composition thereof. The following are the best chlorophyll and lipid extraction conditions for biodiesel production using dry biomass of the microalgae Amphiprora sp: a temperature of $45^{\circ} \mathrm{C}$, a time of $4 \mathrm{~h}$ and a biomass/solvent ratio of $1 / 10 \mathrm{~g} / \mathrm{mL}$.

- The statistical analysis of the results showed that the biomass/solvent ratio is the only significant variable for the extraction of chlorophyll-a, and less significant (but more influential than the other variables: temperature and time) in the extraction of crude oil.

- Incorporating a chlorophyll extraction stage in a largescale biorefinery process using microalgae is only convenient from the process efficiency standpoint when executed before the biomass drying stage, because the elimination of moisture from the strains to increase the efficiency of fermentable sugar and oil extraction degrades the primary and secondary pigments of high commercial value.

\section{ACKNOWLEDGEMENTS}

The authors would like to thank the Colombian Ministry of Agriculture and Rural Development: project 2008D32006-6710 "Bioprospecting of Colombian microalgae for biodiesel production"; Erika Amaya and Lina García for their valuable technical assistance in the experimental portion of the study; the Administrative Department for Science, Technology and Innovation - COLCIENCIAS, for supporting this study through the Francisco José de Caldas scholarships to support national Doctorates; and the project "Creation and Strengthening of a Network to Transfer Knowledge and Technology between the United States and Colombia for the Development of Biorefinery Processes for the 
Production of Biofuels and High-value Products from Microalgae Biomass".

\section{REFERENCES}

Amaro, H., Guedes, C. \& Malcata, X. (2011). Advances and perspectives in using microalgae to produce biodiesel, Appl. Energy, 88(10), 3402-3410.

Archanaa, S., Moise, S. \& Suraishkumar, G. (2012). Chlorophyll interference in microalgal lipid quantification through the Bligh and Dyer method. Biomass Bioenergy, 46: 805-808.

Chisti, Y. (2007). Biodiesel from microalgae. Biot. Adv., 25(3), 294-306.

EPA. (2011). Inventory of US greenhouse gas emissions and sinks: 1990-2009 (April 2011), US EPA \#430-R-11-005.

Ehimen, E. A., Sun, Z. F. \& Carrington, C. G. (2010). Variables affecting the in situ transesterification of microalgae lipids. Fuel, 89(3), 677-684.

Garzón-Sanabria, A. J., Davis, R. T. \& Nikolov, Z. (2012). Harvesting Nannochloris oculata by organic electrolyte flocculation: Effect of initial cell density, ionic strength, coagulant dogase, and media pH. Bioresource Technol., 118(1), 418-424.

González-Delgado, A. D. \& Kafarov, V. (2011). Microalgae based biorefinery: Issues to consider. CT\&F - Ciencia Tecnología y Futuro, 4(4), 5-21.

González-Delgado, A. D. \& Kafarov, V. (2012). Design and adjustment of coupled microalgae oil extraction methods for the development of a topology of biorefinery. Prospectiva, 10(1), 113-123.

Halim, R., Danquah, M. K. \& Webley, P. A. (2012). Extraction of oil from microalgae for biodiesel production: A review. Biot. Adv., 30(3), 709-732.

Handler, R. M., Canter, C. E., Kalnes, T. N., Lupton, F. S., Kholiqov, O., Shonnard, D. R. \& Blowers, P. (2012). Evaluation of environmental impacts from microalgae cultivation in open-air raceway ponds: Analysis of the prior literature and investigation of wide variance in predicted impacts. Algal Research, 1(1), 83-92.
Mata, T. M., Martins, A. A. \& Caetano, N. S. (2010). Microalgae for biodiesel production and other applications: a review. Renew. Sustain. Energy. Rev., 14(1), 217-232.

Ofori-Boateng, C., Teong, L. K. \& JitKang, L. (2012). Feasibility study of microalgal and jatropha biodiesel production plants: exergy analysis approach. Appl. Therm. Eng., 36(1), 141-151.

Pegallapati, A. K., Arudchelvam, Y. \& Nirmalakhandan, N. (2012). Energy-efficient photobioreactor configuration for algal biomass production. Bioresource Technol., 126(1), 266-273.

Peralta-Ruiz, Y., González-Delgado, A. D. \& Kafarov, V. (2013). Evaluation of alternatives for microalgae oil extraction based on exergy analysis. Appl. Energ., 101: 226-236.

Pragya, N., Pandey, K. K. \& Sahoo, P. K. (2013). A review on harvesting, oil extraction and biofuels production technologies from microalgae. Renew. Sustain. Energy. Rev., 24: 159-171.

Ramírez, L. \& Olvera, R. (2006). Uso tradicional y actual de Spirulina sp. (Arthrospira sp.). Interciencia. 31(9), 657-663.

Richmond, A. (2004). Handbook of microalgal culture: Biotechnology and applied phycology. Ames: Blackwell Science.

Schumann, R., Häubner, N., Klausch, S. \& Karsten, U. (2005). Chlorophyll extraction methods for the quantification of green microalgae colonizing building facades. Int. Biodeter. Biodegr., 555(3), 213-222.

Silveira, S. T., Burkert, J. F. M., Costa, J. A. V., Burkert, C. A. V. \& Kalil, S. J. (2007). Optimization of phycocyanin extraction from Spirulina platensis using factorial design. Bioresource Technol., 98(8), 1629-1634.

Singh, P. \& Singh, A. (2011). Production of liquid biofuels from renewable resources. Progr. Energ. Combust. Sci., 37(1), 52-68.

Tverberg, G. E. (2012). Oil supply limits and the continuing financial crisis. Energy, 37(1), 27-34.

Wijffels, R., Barbosa, M. \& Eppink, M. (2010). Microalgae for the production of bulk chemicals and biofuels. Biofuels, Bioprod. Biorefin., 4(3), 287-295. 


\section{AUTHORS}

\section{Ángel-Darío González-Delgado}

Affiliation: Universidad de San Buenaventura.

Chemical Engineering, Universidad Industrial de Santander.

Ph.D. (C) Chemical Engineering, Universidad Industrial

de Santander

e-mail: agonzalezd@usbctg.edu.co

\section{Andrés-Fernando Barajas-Solano}

Affiliation: Universidad Industrial de Santander.

Biologist, Universidad Industrial de Santander.

Ph.D. (C) Chemical Engineering, Universidad Industrial

de Santander.

e-mail: andresfdobarajas@gmail.com

\section{Viatcheslav Kafarov}

Affiliation: Universidad Industrial de Santander.

Cybernetics on Chemical Engineering Processes, Universidad Rusa

de Tecnología Química D I Mendeleyev.

M.Sc. Apllied Mathematics, Universidad Estatal Lomonosov

de Moscú.

Ph. D. Ingenier Habil, Martin Luther Universität Halle Wittenberg.

Ph.D. Technical Sciences, Universidad Rusa de Tecnología Química

D I Mendeleyev.

e-mail: kafarov@uis.edu.co

\section{NOTATION}

Chl-a Chlorophyll concentration in milligrams per liter.

$A_{650}$

Absorbance of a sample at $650 \mathrm{~nm}$, dimensionless.

$A_{665}$

$\%$ ext

Absorbance of a sample at $665 \mathrm{~nm}$, dimensionless.

Mcomp. Mass of the component removed in grams.

Mbiomass Mass of the microalgae sample used in grams. 